Artikel Penelitian

\title{
Pengaruh Lama Pemaparan Obat Antinyamuk Elektrik-mat Berbahan Aktif Allethrin Terhadap Aktivitas Katalase Tikus
}

\author{
Karolin Trisnawelda ${ }^{1}$,Eti Yerizel $^{2}$,Lili Irawati ${ }^{3}$
}

\begin{abstract}
Abstrak
Penggunaan obat antinyamuk elektrik mat telah banyak menggantikan penggunaan obat antinyamuk konvensional lain, dengan allethrin sebagai bahan aktif pada umumnya. Tujuan penelitian ini adalah menentukan pengaruh lama pemaparan obat antinyamuk terhadap aktivitas katalase sebagai marker radikal bebas. Penelitian eksperimental post test only control group design ini dilakukan di Laboratorium FMIPA dan Laboratorium Biokimia FK UNAND dari September 2013 sampai April 2014. Dua belas ekor tikus wistar jantan (usia 2-3 bulan) dengan berat 180-200 gr dibagi dalam 3 kelompok, dengan jumlah 4 ekor per kelompok. Obat antinyamuk elektrik mat berbahan aktif allethrin (7.42 MV/mat) dipaparkan pada 3 kelompok tikus yaitu kontrol, P1 selama 8 jam/hari (10pm6am) dan P2 selama 12 jam/hari (6 p.m-6 a.m) selama 30 hari. Pada hari terakhir penelitian, dilakukan penghitungan aktivitas katalase serum tikus. Hasil menunjukkan penurunan aktivitas katalase serum tikus P2 $(1.10 \pm 0.005 \mathrm{U} / \mathrm{mg})$ dibandingkan dengan nilai yang diperoleh pada P1 $(1.20 \pm 0.064 \mathrm{U} / \mathrm{mg})$ dan kontrol $(1.64 \pm 0.029 \mathrm{U} / \mathrm{mg})$. Didapatkan perbedaan bermakna kadar aktivitas katalase tikus kontrol dan kedua tikus perlakuan $(p<0.05)$. Hubungan antara lama pemaparan obat antinyamuk elektrik mat dan aktivitas katalase pada serum tikus ditunjukkan oleh nilai $r=-0.97$ pada tes korelasi pearson. Disimpulkan bahwa obat antinyamuk elektrik mat berbahan aktif allethrin berpengaruh terhadap aktivitas katalase pada serum tikus.
\end{abstract}

Kata kunci: allethrin, obat antinyamuk elektrik mat, katalase

\section{Abstract}

The usage of electric mosquito repellent containing allethrin as active materials, generally has replaced the usage of other traditional mosquito repellent. The objective of this study was to determne the effect of the time duration of allethrin mat electric mosquito repellent on catalase activity as a free radical marker. The experimental study post test only control group design has been done in Faculty of Science laboratory and Department of Biochemistry Faculty of Medicine at Andalas University in September 2013 until April 2014. Twelve male wistar rats (8-12 weeks old) weighing 180-200 $\mathrm{g}$ were divided into three groups of four rats each. Mosquito mats containing allethrin (7,42 MV/mat) has been tested for 30 days in 3 groups of rats such as control group, P1 group for 8 hours/day (from 10 p.m to 6 a.m) and $P 2$ group for 12 hours/day (from 6 p.m to 6 a.m). The count of rats catalase activity was done at the last day of experiment. The result of study shows decrease in catalase activity of rats serum P2 $(1.10 \pm 0.005 \mathrm{U} / \mathrm{mg})$ when compared to the value obtained from P1 $(1.20 \pm 0.064 \mathrm{U} / \mathrm{mg})$ and control $(1.64 \pm 0.029 \mathrm{U} / \mathrm{mg})$. Furthermore, there was a significant difference in catalase activity rate between control group and both exposure group $(p<0.05)$. The relation between the time duration of allethrin mat electric mosquito repellent and the catalase activity of rats serum value shown by $r=-0.97$ in pearson correlation test. It is concluded that catalase activity of rats serum was affected by allethrin mat electric mosquito repellent.

Keywords: allethrin, mat electric mosquito repellent, catalase

Affiliasi penulis: 1. Prodi Profesi Dokter FK Unand (Fakultas Kedokteran Universitas Andalas Padang), 2. Bagian Biokimia FK Unand, 3. Bagian Fisika FK Unand
Korespondensi: Karolin Trisnawelda, Email:echizen.welda@gmail.com, Telp: 081993867700 


\section{PENDAHULUAN}

Beberapa tahun terakhir, terjadi peningkatan penyakit yang ditularkan melalui nyamuk, diantaranya adalah demam berdarah dengue (DBD) dengan vektor nyamuk Aedes aegypti, penyakit malaria dengan vektor nyamuk Anopheles betina dan penyakit filariasis dengan vektor nyamuk Anopheles, Aedes, Culex, Mansonia dan Armigeres. ${ }^{1,3}$

Peningkatan penyakit yang ditularkan melalui nyamuk mengakibatkan pentingnya pengontrolan. ${ }^{4}$ Berbagai macam cara pengontrolan nyamuk telah dikembangkan, mulai dari obat antinyamuk konvensional seperti obat antinyamuk bakar hingga obat antinyamuk elektrik. Obat antinyamuk bakar mengeluarkan asap sebagai produk sampingan dari proses pembakarannya sehingga mulai ditinggalkan oleh masyarakat. Penggunaan obat antinyamuk semprot harus dilakukan secara manual sehingga masyarakat lebih memilih dan beralih pada penggunaan obat antinyamuk elektrik, baik dalam bentuk cair maupun yang menggunakan mat karena pemakaiannya yang lebih mudah dan lebih efektif.

Obat antinyamuk elektrik mat sebagai salah satu pengganti penggunaan obat antinyamuk konvensional mempunyai beberapa keuntungan, diantaranya yaitu tidak menghasilkan asap, tahan lama, wangi dan mudah digunakan. Karena tertipu oleh wanginya, pengguna obat antinyamuk elektrik mat ini tidak merasakan bahwa dirinya menghirup senyawa berbahaya. ${ }^{5}$ Obat antinyamuk elektrik mat terdiri atas pemanas yang menggunakan listrik dan mat sebagai anti nyamuknya. ${ }^{5}$ Ketika dipanaskan, cairan dalam mat akan menguap dan dilepaskan ke udara. $^{6}$

Salah satu cara pengontrolan nyamuk secara kimiawi, antinyamuk elektrik mat menggunakan bahan kimia yang cukup berbahaya. Salah satu kandungan obat antinyamuk elektrik mat yang banyak digunakan adalah allethrin., ${ }^{5,7}$ Allethrin termasuk ke dalam golongan pyrethroid dengan rumus kimia $\mathrm{C}_{19} \mathrm{H}_{26} \mathrm{O}_{3}$ yang jika terakumulasi dalam tubuh dapat membentuk radikal bebas. ${ }^{5,7}$

Radikal bebas merupakan radikal yang membawa elektron tidak berpasangan, sangat reaktif dan waktu paruh yang sangat pendek $\left(10^{-5}\right)$ detik atau kurang dalam larutan cairan). ${ }^{8}$ Radikal bebas dapat menyebabkan modifikasi dari lipid, protein dan DNA yang merugikan dan diimplikasikan pada proses penuaan serta berbagai macam penyakit pada manusia. $^{9}$

Allethrin menginduksi terjadinya toksisitas melalui stress oksidatif dengan memproduksi radikal bebas. ${ }^{10}$ Salah satu bentuk radikal bebas yang berbahaya adalah hidrogen peroksida. Hidrogen peroksida dibentuk sebagai hasil sisa metabolisme tubuh yang bersifat toksik. Hidrogen Peroksida dapat membentuk radikal hidroksil yang berbahaya melalui reaksi Fenton dan Haber-Weiss. ${ }^{11}$ Akibat pemaparan dari berbagai radikal bebas, maka makhluk hidup mengembangkan beberapa mekanisme pertahanan, salah satunya adalah pertahanan antioksidan enzimatik yaitu katalase. $^{12}$

Katalase merupakan salah satu parameter yang dapat digunakan untuk mengindikasikan adanya radikal bebas dalam sel darah merah. ${ }^{13}$ Katalase merupakan protein yang terdapat di semua sel aerob pada jaringan tubuh, terutama pada hati dan eritrosit. ${ }^{13}$ Katalase dipilih karena ia merupakan marker radikal bebas yang mampu mereduksi hidrogen peroksida ke bentuk oksigen dan air yang tidak berbahaya. ${ }^{13}$ Penelitian dilakukan dengan lama pemaparan allethrin 8 jam/hari (asumsi jumlah jam tidur yang dianjurkan/hari) ${ }^{7,10,14,15}$ dan 12 jam/hari (asumsi pengusiran nyamuk dalam ruangan dari jam 6 sore sampai jam 6 pagi) ${ }^{5}$ pada tikus selama 30 hari sebagai uji toksisitas subkronisuntuk melihat pengaruh pemaparan terhadap aktivitas katalase tikus.

\section{METODE}

Penelitian eksperimental post test only control group design dilakukan pada September 2013 hingga April 2014 di laboratorium FMIPA dan Departemen Biokimia Fakultas Kedokteran UNAND dengan tikus sebagai hewan coba. Tikus yang digunakan adalah tikus wistar keturunan murni, jantan, usia 2-3 bulan, aktif dan berat badan 180-200gr. Jumlah sampel total sebanyak 12 ekor tikus.

Selama penelitian, tikus ditempatkan pada kandang dan diberi makan dan minum yang cukup secara ad libitum setiap hari. Setelah aklimatisasi 
selama 7 hari, tikus dibagi secara random ke dalam tiga kelompok yaitu kelompok kontrol $(\mathrm{K})$ dimana tikus tidak dipapar dengan obat antinyamuk elektrik mat, kelompok perlakuan 1 (P1) dengan paparan obat antinyamuk elektrik mat selama 8 jam/hari (asumsi jumlah jam tidur yang dianjurkan/hari) ${ }^{5,7,10,14,15}$ dari jam 22.00 - 06.00 WIB, dan kelompok perlakuan 2 (P2) dengan paparan obat antinyamuk elektrik mat selama 12 jam/hari (asumsi pengusiran nyamuk dalam ruangan dari jam 6 sore sampai jam 6 pagi $)^{5,7}$ dari jam 18.00 - 06.00 WIB selama 30 hari.

Tikus ditimbang berat badannya setiap tiga hari sekali. Pada hari ke-30 dilakukan pengambilan serum tikus dan dilakukan penghitungan aktivitas katalase tikus dengan alat sfektrofotometer UV-200RS. Uji aktivitas katalase dilakukan di laboratorium Biokimia FK Unand dengan metode Kalorimetrik yang menggunakan warna sebagai indikator .Satu unit aktivitas katalase dinyatakan sebagai banyaknya $\mathrm{H}_{2}$

$\mathrm{O}_{2}$ (dalam mikromol) yang dihancurkan oleh katalase per menit dalam tiap $1 \mathrm{mg} / \mathrm{ml}$ protein.

Data yang diperoleh berupa data aktivitas katalase tikus sebagai variabel terikat dan lama pemaparan obat antinyamuk elektrik mat berbahan aktif allethrin sebagai variabel bebas. Data dianalisis.menggunakan uji one-way ANOVA, uji Post hoc dan uji korelasi Pearson.

\section{HASIL}

Tabel 1. Rerata aktivitas katalase pada semua kelompok penelitian

\begin{tabular}{ccccc}
\hline Group & $\mathbf{n}$ & $\begin{array}{c}\text { Lama } \\
\text { pemaparan } \\
\text { (jam/hr) }\end{array}$ & $\begin{array}{c}\text { Rerata } \pm \text { SD } \\
(\mathbf{U} / \mathbf{m g})\end{array}$ & $\begin{array}{c}\text { Nilai } \\
\text { distribusi } \\
\text { (p) }\end{array}$ \\
\hline Kontrol & 4 & 0 & $1.64 \pm$ & 0.25 \\
P1 & 4 & 8 & 0.029 & \\
& & & 0.064 & 0.30 \\
$\mathrm{P} 2$ & 4 & 12 & $1.10 \pm$ & 0.44 \\
& & & 0,005 & \\
\hline
\end{tabular}

Berdasarkan Tabel 1. dapat dilihat bahwa kelompok kontrol memiliki rata-rata aktivitas katalase sebesar $1.64 \mathrm{U} / \mathrm{mg}$. Kelompok perlakuan 1 dengan lama pemaparan obat antinyamuk elektrik mat 8 jam/hari memiliki rata-rata aktivitas katalase sebesar $1.20 \mathrm{U} / \mathrm{mg}$. Adanya penurunan aktivitas katalase dibandingkan dengan kelompok kontrol. Pada kelompok perlakuan 2 dengan lama pemaparan obat antinyamuk elektrik mat $12 \mathrm{jam} /$ hari didapatkan hasil aktivitas katalase $1.10 \mathrm{U} / \mathrm{mg}$, dimana terjadi penurunan aktivitas katalase dibandingkan kelompok perlakuan 1. Nilai distribusi pada uji kolmogorovsmirnov menunjukkan $\mathrm{p}>0.05$ yang artinya data terdistribusi normal.

Gambaran penurunan aktivitas katalase akibat pemaparan obat antinyamuk elektrik mat disajikan dalam bentuk diagram batang berikut.

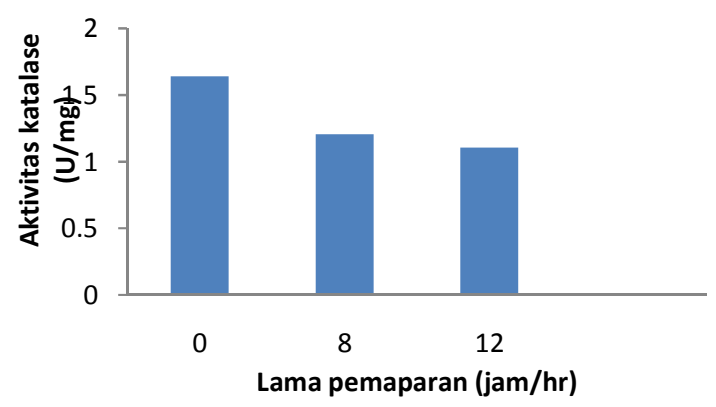

Gambar 1. Diagram batang rerata aktivitas katalase semua kelompok

Adanya penurunan aktivitas katalase dari lama pemaparan 0 jam/hari $(1.64 \mathrm{U} / \mathrm{mg})$ hingga lama pemaparan 12 jam/hari (1.20 U/mg) yang menunjukkan semakin lama pemaparan, maka aktivitas katalase semakin turun.

Tabel 2. Hubungan aktivitas katalase antara semua kelompok penelitian

\begin{tabular}{cccc}
\hline Kelompok & $\mathbf{K}$ & $\mathbf{P 1}$ & $\mathbf{P 2}$ \\
\hline $\mathrm{K}$ & - & $0.00^{*}$ & $0.00^{*}$ \\
$\mathrm{P} 1$ & $0.00^{*}$ & - & 0.11 \\
P2 & $0.00^{*}$ & 0.11 & - \\
\hline
\end{tabular}

Berdasarkan Tabel 2.mengenai hubungan aktivitas katalase antara semua kelompok penelitian, didapatkan bahwa antara kelompok kontrol dan kelompk perlakuan 1 terdapat perbedaan bermakna $(p<0.05)$. Demikian juga antara kelompok kontrol dan kelompok perlakuan 2 juga terdapat perbedaan bermakna $(p<0.05)$. Sedangkan antara kelompok perlakuan 1 dan kelompok perlakuan 2 tidak terdapat perbedaan bermakna, dimana $p=0.11(p>0.05)$. 
Tabel 3. Hubungan antara lama pemaparan obat antinyamuk elektrik mat berbahan aktif allethrin dengan aktivitas katalase tikus

\begin{tabular}{ccc}
\hline & $\mathbf{p}$ & $\mathbf{r}$ \\
\cline { 2 - 3 } $\begin{array}{c}\text { Korelasi aktivitas katalase } \\
\text { dan lama pemaparan }\end{array}$ & 0.00 & -0.97 \\
\hline
\end{tabular}

Pada Tabel 3.mengenai hubungan antara lama pemaparan obat antinyamuk elektrik mat berbahan aktif allethrin dengan aktivitas katalase tikus didapatkan nilai koefisien korelasi negatif $(r=$ 0.97).Nilai Sig $(0.00)<a$ maka Ho ditolak, yang menandakan ada hubungan antara lama pemaparan dengan aktivitas katalase.

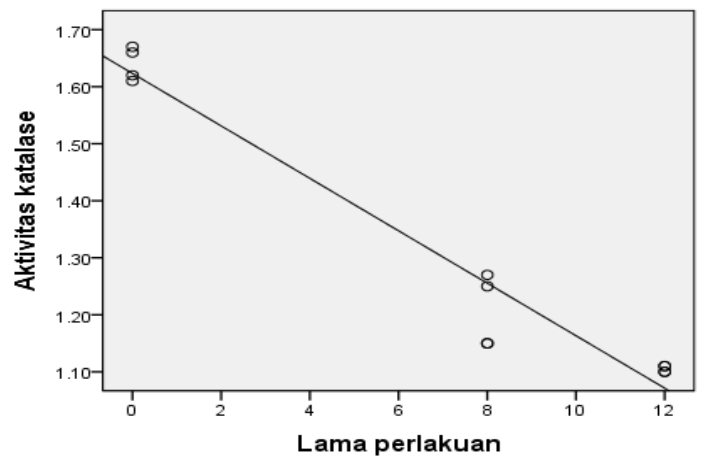

Gambar 2.Korelasi negatif antara lama pemaparan dan aktivitas katalase

Nilai $r=0.75-0.99$ menunjukkan hubungan sangat kuat antara aktivitas katalase dan lama pemaparan obat antinyamuk elektrik mat. Pada Gambar 3 dapat dilihat adanya perbandingan terbalik antara aktivitas katalase dan lama pemaparan obat antinyamuk elektrik mat yang ditunjukkan oleh nilai negatif $(-)$ pada hasil korelasi $(r=-0.97)$.

\section{PEMBAHASAN}

Allethrin merupakan sumber radikal bebas eksogen. Allethrin bersifat lipofilik sehingga dapat masuk ke jaringan, termasuk sistem saraf dan memodifikasi susunan membran lipid bilayer yang mengakibatkan kerusakan dan ketidakstabilan membrane. ${ }^{15,16}$ Saat oksigen menerima satu elektron, terbentuk radikal superoksida yang jika menerima satu elektron lagi tereduksi menjadi hidogen peroksida. Hidrogen peroksida tergolong pada ROS yang berperan sebagai agen oksidasi yang dapat menerima satu elektron dan membentuk radikal hidroksil dengan metal transisi seperti $\mathrm{Fe} 2+$ atau $\mathrm{Cu}+$ melalui reaksi Fenton atau dengan superoksida melalui reaksi Haber-Weiss. ${ }^{10,11}$ Radikal hidroksil merupakan mediator penting penyebab kerusakan struktur sel, asam nukleat, lipid dan protein. ${ }^{12}$ Sebagai mekanisme pertahanan, sel akan menjaga keseimbangan dengan pembentukan senyawa atau reaksi yang bersifat antioksidan, salah satunya yaitu dengan antioksidan enzimatik katalase yang menghambat oksidasi dengan mereduksi hidrogen peroksida ke bentuk oksigen dan air yang tidak berbahaya bagi tubuh. ${ }^{10-12,17}$

Pada kondisi awal terbentuknya radikal bebas, terjadi peningkatan pembentukan senyawa antioksidan. Peningkatan ROS yang berkelanjutan dapat terjadi penurunan kemampuan sel akibat kerusakan makromolekul seperti membran ataupun protein lainnya yang dapat mengakibatkan peningkatan kebocoran radikal oksigen di mitokondria, gangguan pompa elektron dan gangguan fungsi enzim. Hal inilah yang menyebabkan penurunan aktivitas antioksidan tubuh, salah satunya yaitu penurunan enzim katalase. ${ }^{17}$ Hasil ini sesuai dengan penelitian Sinha et al yang menyatakan adanya pengaruh pemaparan obat antinyamuk terhadap penurunan beberapa jenis antioksidan di berbagai bagian otak, termasuk katalase. ${ }^{18}$

Hubungan aktivitas katalase antara semua kelompok penelitian, antara kelompok kontrol dan kedua kelompok perlakuan didapatkan perbedaan bermakna $(p<0.05)$. Hasil penelitian ini sejalan dengan yang dilakukan oleh Akuna et al dimana dilakukan pemaparan dengan obat nyamuk pada tikus selama 8 jam dan 14 jam setiap hari selama 16 minggu dan didapatkan perbedaan bermakna $(p<0.05)$ pada aktivitas katalase antara kelompok tikus perlakuan dan kelompok tikus kontrol. ${ }^{10}$

Hubungan antara lama pemaparan obat antinyamuk elektrik mat berbahan aktif allethrin dan aktivitas katalase didapatkan korelasi negatif $(r=-0.97)$ yaitu hubungan sangat kuat. Hubungan sangat kuat menandakan adanya kaitan yang erat antara lama 
pemaparan dan penurunan aktivitas katalase. Disimpulkan, semakin lama pemaparan, maka semakin banyak radikal bebas yang terbentuk, akibatnya terjadi stress oksidatif dan mengakibatkan tubuh tidak mampu mengkompensasi pembentukan radikal bebas, akibatnya terjadi penurunan antioksidan endogen tubuh. Radikal hidroksil sangat berbahaya karena dapat merusak protein, polisakarida, asam nukleat dan PUFA (Poly Unsaturated Fatty Acid) sehingga dapat menyebabkan stress oksidatif. ${ }^{11}$ Katalase lebih berperan pada peningkatan hidrogen peroksida di dalam sel karena fungsinya yang mengkatalisasi penguraian hidrogen peroksida. ${ }^{17}$ Akibat stress oksidatif, terjadi penurunan kemampuan sel dalam mengatasi pembentukan radikal bebas yang menyebabkan penurunan antioksidan tubuh, salah satunya katalase. ${ }^{10,17}$ Hasil ini sesuai dengan penelitian Manohar et al yang menunjukkan adanya korelasi negatif antara lama pemaparan radikal bebas dan penurunan antioksidan endogen tubuh. ${ }^{19}$

\section{SIMPULAN}

Terdapat pengaruh pemaparan obat antinyamuk elektrik mat terhadap penurunan aktivitas katalase.

Terdapat perbedaan bermakna pada kadar aktivitas katalase antara tikus yang terpapar dan tidak terpapar oleh obat antinyamuk elektrik mat.

\section{DAFTAR PUSTAKA}

1. Kementerian Kesehatan Republik Indonesia. Demam berdarah dengue. Buletin Jendela Epidemiologi. Jakarta: 2010; 2:1-8.

2. Kementerian Kesehatan Republik Indonesia. Epidemiologi malaria di Indonesia. Buletin Jendela Data Dan Informasi Kesehatan. Jakarta: 2011;1: 1-8.

3. Kementerian Kesehatan Republik Indonesia. Filariasis di Indonesia. Buletin Jendela Epidemiologi. Jakarta: 2010;1:1-8.

4. Patel, Gupta, Oswal. A review on: mosquito repellent methods. India : IJPCBS (International Journal of Pharmaceutical, Chemical And Biological Sciences); 2012;2(3):310-7.
5. Aryani R, Kurniati R, Rahmawati S. Pengaruh pemakaian obat antinyamuk elektrik berbahan aktif d-allethrin terhadap leukosit dan trombosit mencit (Mus musculus L). Mulawarman Scientific. 2012; 11(1):101-10.

6. Adanan CR, Zairi J, NG KH. Efficacy and sublethal effects of mosquito mats on aedes aegypti and culex quinquefasciaus (Diptera: Culicidae). Malaysia: Universiti Sains Malaysia; 2005.

7. Kurniati R, Aryani R, Rahmawati S, 2011. Jumlah dan motilitas spermatozoa mencit (Mus musculus $L$ ) yang dipapari obat nyamuk elektrik berbahan aktif d-allethrin. Mulawarman Scientific. 2011; 10(2):133-8.

8. Dorland, Newman WA. Kamus kedokteran Dorland. Jakarta: EGC. 2002; 29:1830.

9. Devasagayam TPA, Tilak JC, Boloor KK, Sane KS, Ghaskadbi SS, Lele RD. Free radicals and antioxidants in human health : current status and future prospects. JAPI. 2004; 52:794-804.

10. Akuna GG, Saalu LC, Ogunlade B, Akingbade AM, Ogunmodede OS.Pyrethroid-based insecticide induces testicular toxicity via oxidative pathway: study suggest. Oriental Journal of Scientific Research.Nigeria: Lagos State University; 2013.

11. Collen S, Allan DM, Michael L. Oxygen toxicity and free radical injury. Dalam: Marks' basic medical biochemistry a clinical approach. 2004; 2(24):43959.

12. Valko M, Leibfritz D, Moncol J, Cronin MTD, Mazur M, Telser J. Free Radicals and antioxidants in normal physiological functions and human disease. International Journal of Biochemistry And Cell Biology. 2007; 39:44 - 84.

13. Cadenas E. Free radicals, oxidative stress and diseases. 2005.

14. Srivastava A, Srivastava M, Raizada RB. Ninetyday toxicity and one-generation reproduction study in rats exposed to allethrin-based liquid mosquito repellent. The Journal of Toxicological Sciences; 2006;31(1):1-7.

15. Narendra M, Kavitha G, Padmavathi P, Kiranmai $\mathrm{H}$, Varadacharyulu NC. Allethrin-induced biochemical changes and properties of human 
erythrocyte membrane. African Journal of Biochemistry Research. India: Dept. of Biochemistry, Sri Krishnadevaraya University; 2008; 2(2):24-9.

16. Kakko I. Toxic mechanisms of pyrethroids studied in vitro. Finland: University of Tampere; 2004.

17. Asni E, Harahap IP, Prijanti AR, Wanandi SI, Jusman SWA, Sadikin M. Pengaruh hipoksia berkelanjutan terhadap kadar malondialdehid, glutation tereduksi dan aktivitas katalase ginjal tikus. Majalah Kedokteran Indonesia. 2009; 59(12):595-600.
18. Sinha C, Seth K, Islam F, Chaturvedi RK, Shukla $\mathrm{S}$, Mathur $\mathrm{N}$, et al. Behavioral and neurochemical effects induced by pyrethroid-based mosquito repellent exposure in rat offsprings during prenatal and early postnatal period. India; 2006.

19. Manohar R, Chundru V, Naga S. Study of antioxidant enzymes superoxide dismutase and glutathione peroxidase levels in tobacco chewers and smokers: A pilot study. Journal of Cancer Research and Therapeutics. 2013; 9(2):210-4. 